\title{
On the Physico.chemical and Immunological Properties of Boar Sperm Coating Antigen
}

\author{
Yasuhisa Yasuda and Mutsuo OHARA \\ Faculty of Agriculture, Iwate University, Morioka-shi 020
}

(Received June 15, 1972)

\begin{abstract}
The sperm coating antigen (SCA) which was extracted from boar seminal plasma was studied on the physico-chemical and immunological properties. The extracted SCA is composed of a part of proteins which constitute seminal plasma. An acid buffer gave better fractionation in electrophoresis of SCA. Appearance of two fractions in gel filtration indicates that the SCA exists in testis, epididymis, and seminal vesicle fluid. The fraction by gel filtration roughly agreed with the precipitin titer. The extracled SCA, as tested by the OUCHTERLONY's technique, had antigen system similar to those of seminal plasma and also partly common to those of testis. Immunization of rabbits with the SCA did not interfere with spermatogenesis.
\end{abstract}

The SCA is stable toward heating up to $80^{\circ} \mathrm{C}$ or freezing and resists to some of organic solvents as reported by Liprielio et al.1) In this respect, the SCA may resemble to the decapacitation factor (DF) which is a proteinous, thermally stable substance and interferes with the active surface of the sperm head ${ }^{2}$.

The relationship between SCA (which is called by WEIL and RODENBURG ${ }^{3}$, WeIL ${ }^{4,5}$, HUNTER and NORNES ${ }^{6}$, ROBERTS and BOETTCHER ${ }^{7}$, BARKER and AMANN ${ }^{8}$, as a result of their immunological studies) and $\mathrm{DF}$ (which is called by BEDFORD and $\mathrm{CHANG}^{2)}$ as a result of their reproductive studies) is a theme of research which has attracted some research workers, but still more basic studies will be needed before it is clarified.

We investigated immunological as well as physico-chemical properties of SCA from boar seminal plasma, using gel filtration, paper electrophoresis, starch electrophoresis and OucHTERLONY's technique for immunological studies. At the same time, spermatogenesis of rabbits immunized with the SCA was investigated histologically.

\section{Materials and Methods}

Preparation of sperm coating antigen: The semen used for extraction of SCA was collected from a Yorkshire boar at given intervals with an artificial vagina. The properties of the semen were examined before extraction of SCA and mean values of them were as follows; total volume, $345 \mathrm{ml}$; pH, 8.6; colloidal substances, $51.8 \mathrm{~g}$; viability of spermatozoa, 90 H; number of spermatozoa, $206 \mathrm{million} / \mathrm{m} l$. The preparation of SCA was conducted in modification of the method of HunTER and NORNES ${ }^{\theta}$. The semen was filtered to remove colloidal substances and then centrifuged at $1,000 \mathrm{G}$ for 15 minutes to separate seminal plasma. The seminal plasma was stored in a deep freezer at $-20^{\circ} \mathrm{C}$ until the day before ultracentrifugation was run. Before the ultracentrifugation, the frozen seminal plasma was thawed in a refrigerator 
and centrifuged at $1,000 \mathrm{G}$ for 15 minutes and the supernatant was centrifuged again at $12,000 \mathrm{G}$ for 5 minutes. The supernatant thus obtained was subjected to ultracentrifugation in the Hitachi RP-50 rotor at $105,000 \mathrm{G}$ for 60 minutes, and the sediment was suspended in

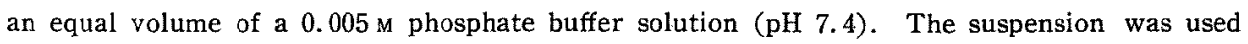
for the SCA preparation.

Electrophoretic studies of sperm coating antigen: Paper electrophoresis was run according to the standard procedure adopted by the society of electrophoresis using the veronal buffer solution ( $\mathrm{pH}$ 8.6, $\mu=0.05$ ) and the Toyo filter paper No. 51A. After electrophoresis, the fractions were dyed with bromphenol blue and the number of fractions and the mobility (Rf value) were examined.

Starch gel electrophoresis was run according to the method of SCHELlPFEFFER and HunTER". The gel was prepared using $0.05 \mathrm{M} \mathrm{LiOH}-0.191 \mathrm{M}$ boric acid buffer ( $\mathrm{pH} 7.5$ ) and $0.028 \mathrm{M}$ tris $-0.008 \mathrm{~m}$ citric acid ( $\mathrm{pH} 7.5$ ) in the electrode cells. Moreover, to find out the difference in fractionation between the electrode solution and buffer solution, formic acid-acetoacetic acid $(\mathrm{pH}$ 1.7) was used in the electrode cells and the gel was prepared after addition of urea to this buffer solution.

Gel filtration was carried out according to the method of Hunter and Nornes ${ }^{6}$ using Sephadex G-25 and Sephadex G-200. The buffer solution in this case was $0.005 \mathrm{M}$ phosphate buffered saline $\left(\mathrm{pH} \mathrm{7.4)}\right.$ and the flow rate was $2.4-3.6 \mathrm{ml} / \mathrm{cm}^{2} / \mathrm{hr}$. The eluates were collected in $3 \mathrm{~m} /$-fractions using fraction collector with the aid of volume count and concentration of protein was determined by the Hitachi spectrophotometer 101 at a wavelength of $280 \mathrm{~m} \mu$.

Immunological studies of sperm coating antigen: The antigens used in accordance with the OUCHTERLONY's technique were SCA, $20 \%$ sperm suspension, seminal plasma separated from ejaculated semen by centrifugation at $1,000 \mathrm{G}$ for 15 minutes, epididymal sperm, and testes, homogenized with an equal volume of $0.85 \% \mathrm{NaCl}$. The epididymal sperm and the testes were collected from a Hampshire boar at slaughter.

Five $\mathrm{m} l$ each of SCA preparation, seminal plasma, and sperm suspension was emulsified with an equal volume of the FREUND's complete adjuvant, and each emulsion was injected to two rabbits. After immunization, the precipitin titer was determined every week, blood was collected in the third week, and each antiserum was obtained by centrifugation at $1,000 \mathrm{G}$ for 5 minutes. The OUCHTERLONY's technique was applied to the combination of these antigens and antisera according to MATSUHASHI's method ${ }^{10}$. The precipitin titer of eluates of SCA in gel filtration with Sepadex G-200 was determined by the anti-SCA serum.

Effects of sperm coating antigen on spermatogenesis: Two rabbits immunized with SCA were slaughtered and the testes were taken out immediately and fixed with $10 \%$ formalin. Paraffin sections in a thickness of $5 \mu$ were prepared, dyed with haematoxylin-eosin and with periodic acid-Schiff, and submitted to histological examination.

\section{Results}

\section{Electrophoresis}

In paper electrophoresis with the use of the veronal bufier solution, SCA showed a single fractionation pattern and its mobility ( $\mathrm{Rf}$ value) corresponded to that of the $\beta$-globulin fraction of boar serum which was subjected to electrophoresis simultaneously.

In starch gel electrophoresis with tris-citric acid $(\mathrm{pH} 7.5)$ as a gel buffer, SCA showed 
On the Properties of Boar SCA

one band on the anode side and two bands on the cathode side. On the other hand, seminal plasma which was subjected to electrophoresis simultaneously showed two to three bands on the cathode side and two bands on the anode side (Fig. 1).

In the electrophoretic pattern with formic acid-acetoacetic acid ( $\mathrm{pH}$ 1.7) as a buffer, however, SCA showed five bands and seminal plasma eight bands on the cathode side (Fig. 2).

The above mentioned electrophoretic results indicate that an acid buffer gives better fractionation than an alkaline buffer.

2. Gel filtration

In gel filtration with Sephadex G-25 as a support, SCA showed only one peake while seminal plasma showed two peaks (Fig. 3). With Sephadex G-200, however, number of peaks in SCA and seminal plasma were two and three, respectively (Fig. 4, 5).

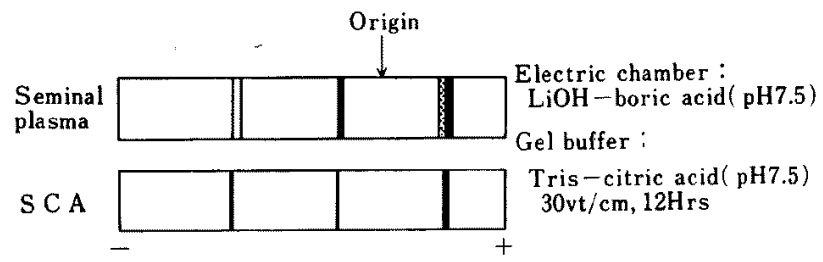

Fig. 1. Diagrams of sperm coating antigen and seminal plasma by starch gel electrophoresis with alkaline buffer ( $\mathrm{pH} 7.5$ )

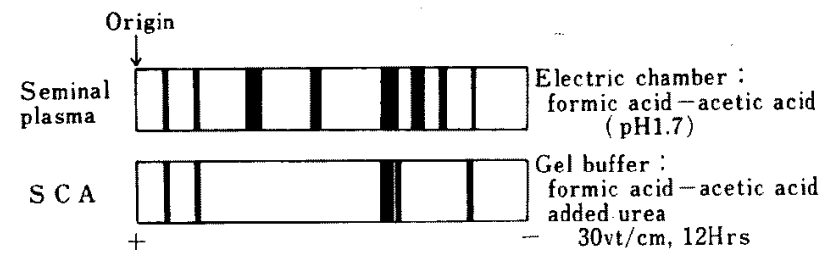

Fig. 2. Diagrams of sperm coating antigen and seminal plasma by starch gel electrophoresis with acid buffer $(\mathrm{pH} 1.7)$

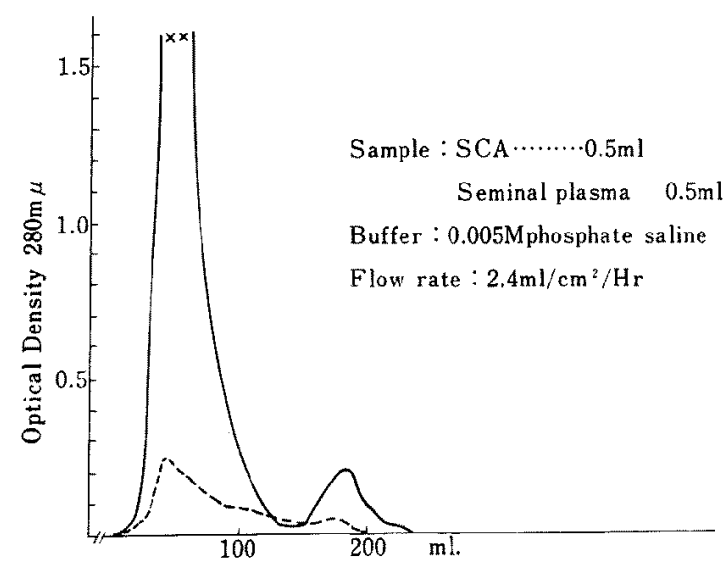

Fig. 3. Diagrams of protein in eluates from Sephadex-G 25 gel filtration of sperm coating antigen and seminal plasma 


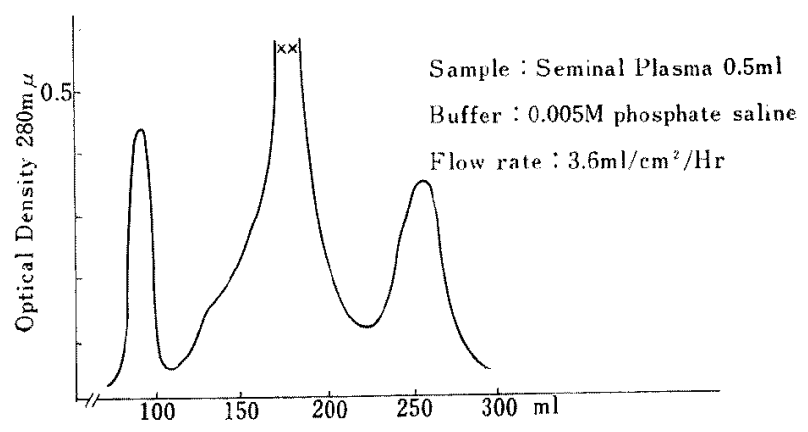

Fig. 4. Diagrams of protein in eluates from Sephadex-G 200 gel filtration of seminal plasma

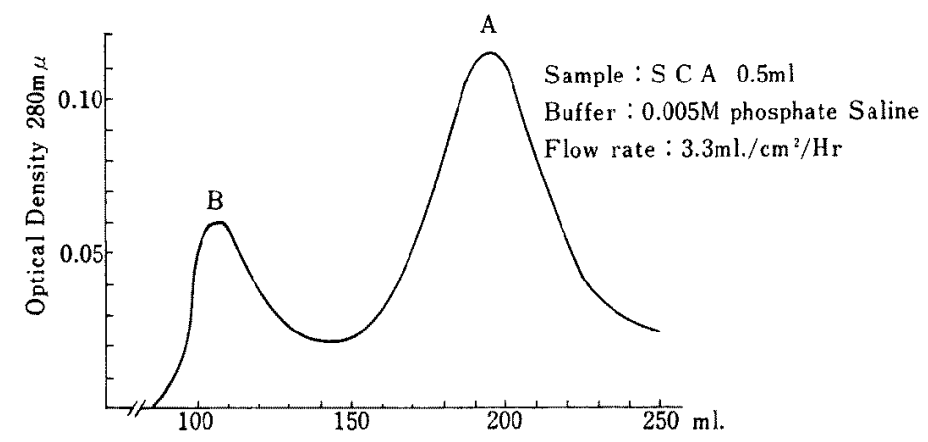

Fig. 5. Diagrams of protein in eluates from Sephacex-G 200 gel filtration of boar sperm coating antigen

\section{Antigen system of SCA}

The testis and seminal vesicle have been cited as a site of production of SCA ${ }^{11}$. Hence, the Ouchterlony's technique was applied to the testis, epididymal sperm, ejaculated sperm, and SCA to examine their interrelationships.

With anti-seminal plasma: Ejaculated sperm and SCA each formed three precipitin lines against anti-seminal plasma, and these lines coincided with each other. Epididymal sperm and SCA each formed three precipitin lines against anti-seminal plasma and two of these lines were common. Furthermore, testis and SCA each formed one common precipitin line against anti-seminal plasma and in addition SCA formed two lines characteristic of it.

With anti-SCA: SCA and seminal plasma formed three and two precipitin lines respectively against anti-SCA and a coincidence was seen for one of these lines.

Precipitin titer of eluates of SCA by gel filtration: The precipitin titer of eluate in gel filtration with Sephadex G-200 was determined against anti-SCA. It was observed that the protein pattern of eluates was roughly proportional to changes in the precipitin titer of SCA (Fig. 6).

4. Spermatogenesis of rabbits immunized with SCA

No inflammation but a number of sperm were observed in seminiferous tubules of the 


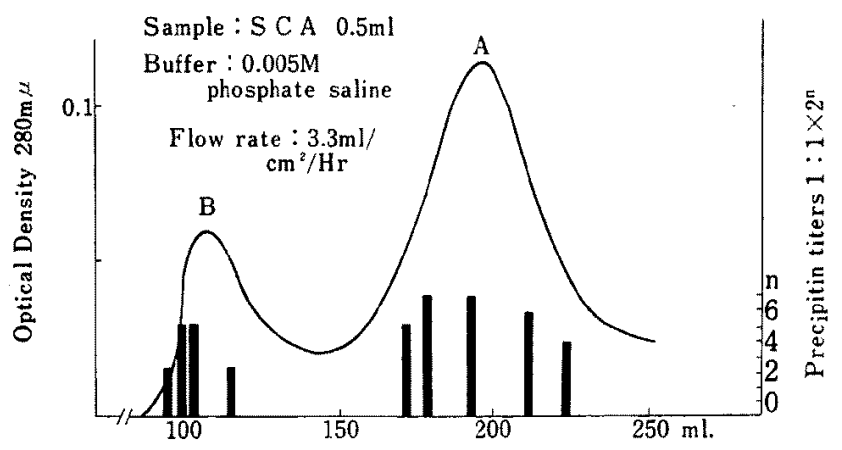

Fig. 6. Diagrams of protein in eluates from Sephadex-G 200 gel filtration of boar sperm coating antigen and localization of antigenic activity

testes of the rabbits immunized with SCA. Hence, interference with spermatogenesis was absent. Practically no multinuclear giant cells appeared except in some seminiferous tubules. Spermatogenesis proceeded normally even in such seminiferous tubules.

\section{Discussion}

It was observed that this SCA from boar seminal plasma corresponds to the $\beta$-globulin fraction in respect to the mobility ( $\mathrm{Rf}$ value) in the paper electrophoresis. This result is in agreement with the report by HUNTER and NORNES ${ }^{6}$ ) that the SCA extracted from a rabbit corresponds to slow $\beta$-globulin.

In starch gel electrophoresis, SCA showed slightly less bands than seminal plasma and the pattern resembled each other. In this respect, only one fraction disappeared also in gel filtration with Sephadex G-200. These results indicate that SCA is composed of a portion of proteins which constitute seminal plasma9'.

The electrophoretic experiments conducted in this study revealed that an acid buffer gives better fractionation than an alkaline buffer. This is in agreement with the report by LAvon et al. ${ }^{12}$,

Seminal plasma gave three peaks in gel filtration with Sephadex G-200 as a support. Regarding this, BouRsNeLl et al. ${ }^{13}$ reported that boar seminal plasma is separated into a heatcoagulating fraction at $2.5 \mathrm{~S}$ and a fraction at 7 or $40 \mathrm{~S}$. They added that a fraction at $7 \mathrm{~S}$ appears separately when seminal plasma is stored in refrigerator.

SCHELLPFEFFER and HUNTER ${ }^{9}$ carried out gel filtration of boar seminal plasma on Sephadex G-200 and separated it into three fractions; fraction $B$ having a molecular weight of about 155,000 and originating in testis and epididymis, fraction $A$ having a molecular weight of about 55,000 and originating in seminal vesicle fluid, and fraction $\mathrm{C}$ having a molecular weight of about 34,000 and originating in genital organs other than the foregoing. Seminal plasma was separated into three fractions in this study. Fraction B and A appeared in the elution curve of SCA as pointed out by SCHELLPFEFFER and HUNTER", but fraction C was absent.

Hence, it is likely that the SCA extracted here originates in testis and epididymis and in seminal vesicle fluid. $\mathrm{LI}_{I}$ and BEHRMAN ${ }^{11}$ ) also reported that seminal vesicle and epididymis 
are the source of secretion of this SCA. However, the source of secretion of SCA, together with the physiological action of SCA, is an important subject of study and will be clarified as the method of purification becomes refined.

With respect to immunological properties of the extracted SCA, WEIL et al. ${ }^{14}$ ) noted no difference between ejaculated sperm and seminal plasma and RAO and SADrI ${ }^{15)}$ mentioned the presence of an antigen system common to sperm and seminal vesicle fluid. It is well known that a fundamental antigen system of ejaculated semen is seminal vesicle fluid ${ }^{16,17}$. Hence, it is conceivable that an antigen system common to seminal vesicle fluid and ejaculated sperm is present but no such system is present for sperm from testis.

The application of the OUCHTERLONY's technique to the SCA extracted in this experiment showed that seminal plasma and SCA are identical in part against anti-SCA. This means, as do the results of electrophoresis, that SCA is composed of proteins which constitute seminal plasma.

The fact that SCA has an antigen system identical with those for seminal plasma and sperm against anti-sperm supports the old concept ${ }^{14}$ that the substance which cannot be removed from sperm by washing is SCA.

Furthermore, it was noted that the extracted SCA has a smaller number of antigen systems common to epididymal sperm than ejaculated sperm, against anti-seminal plasma. This indicates that SCA adheres to sperm during passage through genital tract.

Now, SCA was separated by gel filtration into fraction B originating in testis and epididymis and fraction A originating in seminal vesicle fluid, and the precipitin titer in each test tube was roughly proportional to the peak as a general tendency. This supports the earlier report by LlpPIELLo et al." that the electrophoretic fractionation on Sepharose $2 \mathrm{~B}$ is roughly proportional to the CFT titer.

A histological study of the testes of the rabbits immunized with SCA did not show occurence of aspermatogenesis or oligospermia, and it is unlikely that immunization with SCA affects spermatogenesis of rabbits.

In contrast, immunization of rabbits with the boar sperm suspension caused aspermatogenesis as mentioned earlier ${ }^{9}$. Hence, a difference in working mechanism between SCA and sperm is expected. On the other hand, appearance of multinuclear giant cells in part of seminiferous tubules is probably a result of addition of the complete adjuvant of FREUND.

The authors wish to express their hearty thanks to Professor Dr. T. Niwa, in the Laboratory of Animal Breeding and Reproduction, for his guidance and criticism.

\section{References}

1) Lippiello, L.A., F. El-Rubaye, and A.F.J. Weil, Fertil Steril 19: 991-998. 1968.

2) Bedford, J.M., and M.C. Chang, Am J Physiol 202: 179-181. 1962.

3) Weil, A.J., and J.M. Rodenburg, Proc Soc Exp Biol Med 109: 567-570. 1962.

4) Weil, A.J., Ann NY Acad Sci 124: 267-269. 1965.

5) WeIL, A.J., J Reprod Fert Suppl 2: 25-34. 1967.

6) Hunter, A.G., and H.O. Nornes, J Reprod Fert 20: 419-427. 1969.

7) Roberts, T.K., and B. Boettcher, J Reprod Fert 18: 347-350. 1969.

8) Barker, L.D.S., and R.P. AmAnn, J Reprod Fert 22: 441-452. 1970. 
9) Scellpfeffer, D.A., and A.G. Hunter, J Reprod Fert 23: 291-298. 1970.

10) Matsuhashi, T., J Med Technol 5: 11-15. 1961.

11) LI, T.S., and S.J. Benrman, Fertil Steril 21: 565-573. 1970.

12) Lavon, U., R. Vocani, and D. Danon, J Reprod Fert 24: 219-234. 1971.

13) Boursnell, J.C.M., M. Nelson, and D.E. Cole, J Reprod Fert 11: 139-144. 1966.

14) WeIl, A.J., O. Kotsevalov, and L. Wilson, Proc Soc Exp Biol Med 92: 606-610. 1956.

15) RAo, S.S., and K.K. SADRI, J Comp Path Ther 70: 1-9. 1960.

16) Well, A.J., and A.E. Finkler, Proc Soc Exp Biol Med 98: 794-797. 1958.

17) Yasuda, Y., M. Ohara, S. Kawamura, and Y. Yasuda, Kitasato Arch exp Med 44: 117123. 1971 .

\title{
豚 Sperm Coating Antigen の物理化学的 \\ および免疫学的性質について
}

\author{
安田泰久・大原睦生 \\ 岩手大学農学部, 盛岡市 020
}

著者らは, 豚 Sperm Coating Antigen (SCA) の物 理化学的および 免疫学的性質を追水するため電気泳動 洼,ゲル沪過法および寒天内沈降反椨を用いて検討した。

SCA 法 HUNTER の方洼に基ついて豚精獎から抽出し， 物理化学的性質の検討は，犬゙ナール䌅衝液 $(\mathrm{pH} 8.6$ $\mu=0.05)$ を用いた沪紙電気泳動法と，ゲルを $0.005 \mathrm{M}$

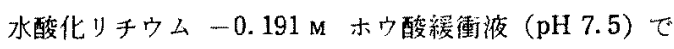
作り, 電極槽に $0.028 \mathrm{M}$ トリスー $0.008 \mathrm{M}$ クエン酸緩

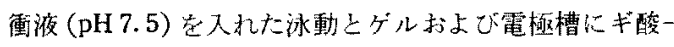
酷酸緩㣫液（pH 1.7）を使用した䬦粉ゲル電気泳動法を 实施した。さらに，Sephadex G-25と G-200を用いた ゲル沪過法を行ない, $3 \mathrm{~m} l$ オ゙つの溶出液を集好て $280 \mathrm{~m} \mu$ の分光光度計で蛋白俩家測定した.

免疫学的検討は，SCA Kフロインドの完全補助物質 をつけて 2 頭のウサギに免疫し，3週後にSCA 抗血清

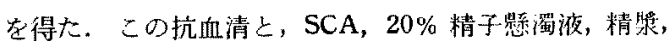
精少上体精子, 身扗精子上堂粗合七七寒天内沈降反応 実施した。ざらに、SCA 死免疫したウサギの精巣を殺処 分捘直ちに採り出し，切片堂作り H-E 染色㧍よび PAS 染色して精子形成阻害について検討した.

その結果, 抽出した SCA は沪紙電気泳動法で同時に 泳動した血清の $\beta$-分画に相当し，澱粉げル電気泳動法 ては，精漿を構成している1部の蛋白成分より成立って いることが認められた。ゲル沪過法では，SCA は2つ の分画に分けられ，精紧扩よび精栄上体に由来方る分画 と精のう淮に由来与る分画之考光られた。

寒天内沈降段応加ら， SCA は精のう液上其通な抗原 系をもち，精坚とは一部共通な抗原系が認妨的たた。 お，SCA 兔疫ウサギに精子形成阻害は認められなか。 た. 